\title{
Comment
}

\section{State Activism and State Censorship}

\author{
Owen M. Fisst
}

Recent political debates prompted by the Supreme Court's flag burning decisions have once more demonstrated the depth of the nation's commitment to freedom of speech. ${ }^{1}$ Although the Court's determination to treat flag burning as an act of political expression, and thus to protect it from state interference, provoked a strong, hostile response from both the President and members of Congress, leading some to call for a constitutional amendment, the campaign to reverse the Court on this issue quickly faded. There was a sense in the body politic that the First Amendment is not simply a technical legal rule, to be amended whenever it produces inconvenient results, but rather an organizing principle of society, central to our self-understanding as a nation and foundational to a vast network of highly cherished social practices and institutions. It can be amended only at the risk of changing the very nature of society. The principle of freedom that the First Amendment embodies is derived from the

$\dagger$ Alexander M. Bickel Professor of Public Law, Yale University. The work of an extraordinary group of students-Amy Adler, Jennifer K. Brown, Elizabeth E. deGrazia, Don Hawthorne, David Solomon, and Anne P. Standley-helped me enormously on this project.

1. United States v. Eichman, 110 S. Ct. 2404 (1990); Texas v. Johnson, 491 U.S. 397 (1989); see Measures to Protect the American Flag: Hearings Before the Senate Comm. on the Judiciary Proposing an Amendment to the Constitution Authorizing the Congress and the States to Prohibit the Physical Desecration of the American Flag, 101st Cong., 2d Sess. (1990); Measures to Protect the Physical Integrity of the American Flag: Hearings Before the Senate Comm. on the Judiciary, 101st Cong., 1st Sess. (1989); Statutory and Constitutional Responses to the Supreme Court Decision in Texas v. Johnson: Hearings Before the Subcomm. on Civil and Constitutional Rights of the House Comm. on the Judiciary, 101st Cong., 1st Sess. (1989); Michelman, Saving Old Glory: On Constitutional Iconography, 42 STAN. L. REV. 1337 (1990); Nahmod, The Sacred Flag and the First Amendment, 66 IND. L.J. 511 (1991). 
democratic nature of our society and reflects the belief that robust public debate is an essential precondition for collective self-determination. ${ }^{2}$

That principle has received its most forceful expression in cases involving criminal prosecutions of outspoken critics of the established order for breaching the peace, inciting a riot, conspiring to overthrow the government, seditious libel, or distributing obscene material. At first, the Court erred on the side of the censor, allowing convictions on such charges to stand, but over the last sixty years the Court has placed increasingly stringent limitations on these exercises of state power. The recent flag burning decisions are but an example of this tendency. The state is sometimes allowed to arrest and prosecute speakers-freedom of speech is not absolute-but the Court has developed an elaborate body of doctrine to make certain that criminal interdiction of speech is a most extraordinary occurrence.

In recent years we have come to understand that the state does not act just as policeman, but also as educator, employer, landlord, librarian, broadcaster, banker, and patron of the arts. The twentieth century has witnessed an enormous growth of state power and, even more, a proliferation of the ways in which this power has come to be exercised. In speaking of the rise of the activist state in America, we refer not simply to the quantitative growth of state intervention, but more importantly to the changes in the ways that the state has intervened: a movement from negative to affirmative modalities. This development has been of considerable importance politically and socially and, at the same time, has created new challenges for the First Amendment. Is it an infringement of freedom of speech for a public library to exclude certain radical books? Or for a public school to offer a course on evolution but not creationism? Or for a state-owned television station to promote the development of nuclear power and not provide an opportunity for environmental groups to voice their opposition?

In grappling with these questions the Supreme Court has acknowledged that the First Amendment applies to the affirmative as well as the negative modes of exercising state power, but it has encountered great difficulty in specifying exactly how it applies. Stated in the most general terms, the question is whether the Court should apply a double standard-should the Court be more lax in its review of these affirmative exercises of power than it is when it reviews the enforcement of the criminal law? This is the question I wish to address, and to do so I will focus on the constitutional and political controversy concerning Robert Mapplethorpe and the National Endowment for the Arts (NEA). That controversy was spurred by a number of public statements by Senator Jesse

2. For a consideration of the various theories of the First Amendment, and the argument in favor of viewing the First Amendment more as a protection of collective self-determination than of individual selfexpression, see Fiss, Why the State?, 100 HARV. L. REV. 781 (1987). For a more recent examination of these issues, see Note, A Pluralistic Reading of the First Amendment and Its Relation to Public Discourse, 99 YALE L.J. 925 (1990). 
Helms of North Carolina objecting to the use of public funds to support the show. Although it did not reach the Supreme Court, for more than a year the Mapplethorpe controversy was a matter of national importance. It was in the newspapers almost on a daily basis, resulted in one criminal prosecution, the appointment of a presidential commission and several rounds of legislation, and raised complex issues that every modern democracy must confront in adjusting to the changes in the way state power is exercised.

Robert Mapplethorpe was a successful New York photographer. He was gay and in March 1989 died of AIDS. At that time, he was forty-two years old. Shortly before his death, a retrospective exhibition of his photographs was organized by the Institute for Contemporary Art of the University of Pennsylvania. That exhibition consists of 175 photographs and the subjects of the photographs vary widely. A number of the photographs are portraits of Mapplethorpe himself and of celebrity friends such as Andy Warhol; others portray flowers (lilies or tulips), which are presented in almost sculptural form, as if hewn from cold, inanimate stone. There are also two photographs of children of some of Mapplethorpe's friends: one is of a naked boy, sitting on the back of a chair; another is of a young girl, with her dress raised. She is not wearing undergarments. Still another group of photographs consists of shots of the male body, often heads, but sometimes the naked torso or its various parts. They too appear sculptural. One photograph in this group, entitled "Man in Polyester Suit," is of a black man dressed in an inexpensive suit of clothing with his penis exposed. His head is cropped. A final group of photographs-perhaps the most provocative-depicts homosexual relationships and homosexual activity. In one, two men are kissing ("Larry and Bobby Kissing") and in another, entitled "Embrace," two young men, one black, the other white, both wearing jeans, naked to their waists, are affectionately embracing one another. In addition, a number of photographs, part of the so-called " $x, y, z$ series," include depictions of sexual activity that could be considered sadomasochistic. ${ }^{3}$

Starting in the early part of 1989 and continuing through the fall of 1990 , the show was exhibited in various museums throughout the country. In one locality-Cincinnati, Ohio-a museum and its director were prosecuted for violating a local criminal statute that prohibits the pandering of obscenity. ${ }^{4}$ The

3. The term " $x, y, z$ series" refers to a group of three portfolios. Each portfolio consists of thirteen photographs; each photograph measures $131 / 2$ inches square. The " $\mathrm{X}$ Portfolio" includes scenes that may be considered sadomasochistic, the "Y Portfolio" consists of flowers, and the " $Z$ Portfolio" consists of photographs of black men. When I viewed the show at the Wadsworth Atheneum in Hartford, all three portfolios were mounted on a wall at the end of the exhibition. In some other locations, the "X Portfolio" was displayed horizontally in a glass case, so that museum visitors who passed through the exhibit looking only at the walls would not see it.

4. The prosecution in fact charged the museum and its director with depicting minors in a state of nudity as well as with pandering obscenity. The prosecution singled out seven photographs as the basis for its case: the two of the children and five from the " $x, y, z$ series." In one of the five from the "x, $y, z$ series," a man is urinating into another man's mouth, another shows the tip of a finger inserted into a penis, and the other three each depict a man with an object inserted in his rectum: a bull whip, a cylinder, and a hand. Presumably, the cylindrical object is a dildo, and the hand is clenched in the form of a fist. The 
director faced a fine of up to $\$ 2,000$ and a one year jail sentence if convicted; the museum faced a $\$ 10,000$ fine. The indictment was filed in the spring of 1990 , soon after the opening of the show there, and later that fall, after a highly publicized trial lasting several weeks, the jury voted to acquit. As with any jury decision, it is impossible to know exactly what that verdict turned on-a dislike of the prosecutor? a failure of proof? a belief that pictures are constitutionally protected? a concern for the reputation of Cincinnati? It seems relatively clear, however, that the prosecution could not have survived under established First Amendment doctrine and that the jury would have been reversed if it had decided differently.

In the obscenity context, the Court's strategy has been to limit state censorship by propounding a constitutional definition of obscenity, which then is used to demarcate the outer boundary of state power: Material that does not fall within the narrow parameters of the constitutional definition of obscenity is protected. This strategy, first announced in 1957 in Roth v. United States, evolved through the sixties in cases like the one involving "Fanny Hill,"6 and then received its most recent statement in 1973 in Miller $v$. California. ${ }^{7}$ According to Miller, a conviction for distributing or publishing allegedly obscene material will be allowed to stand if, and only if, the material, taken as a whole, (1) appeals to a prurient interest in $\operatorname{sex}^{8}{ }^{8}(2)$ depicts sexual activity in a patently offensive way, and (3) is without serious aesthetic, political, or scientific value.

In applying this test, the challenged work must be viewed as a whole, ${ }^{9}$ and from that perspective, it is doubtful that the Mapplethorpe exhibition could properly be regarded as either appealing to a prurient interest in sex or depicting sex in a patently offensive way. On these issues there might be some room for disagreement, but the situation is quite different when it comes to applying

catalog of the exhibition, J. KARDON, ROBERT MAPPLETHORPE: THE PERFECT MOMENT (1988), does not contain reproductions of all the photographs in the show, and specifically does not include any from the " $x, y, z$ series" that were targeted by the Cincinnati prosecutor.

5. 354 U.S. 476, 484-85 (1957).

6. A Book Named "John Cleland's Memoirs of a Liaison of Pleasure" v. Massachusetts, 383 U.S. 413 (1966).

7. 413 U.S. 15 (1973).

8. Prurient interest of whom? While the Court in Miller spoke of the "average person," it included "normal or perverted" sexual acts in its examples of what depictions state obscenity laws permissibly could reach, and on other occasions the Court adjusted the standard to take account of the fact that the allegedly obscene material was aimed at a so-called "deviant audience." Pinkus v. United States, 436 U.S. 293, 301-03 (1978); Ward v. Illinois, 431 U.S. 767, 773 (1977); Mishkin v. New York, 383 U.S. 502, 508-10 (1966).

9. The Cincinnati prosecutor's strategy of singling out the two photographs of the children might be explained by the presence of a statute specifically addressed to the display of minors in a state of nudity. But the decision to single out the five other photographs, contrary to the requirement that the work-here the exhibition, or at the very least, the " $x, y, z$, series"--be taken as a whole has led me to wonder whether the prosecutor was trying to sabotage his own case. This speculation is strengthened by the weakness of the prosecutor's case. The prosecution had only four witnesses testify. Three were policemen who confirmed that the exhibition had taken place. The fourth was a so-called communications expert, who, according to the New York Times, "worked with anti-pornography groups and whose primary artistic credential was presented as writing songs for the 'Captain Kangaroo' television show." Obscenity Jurors Were Pulled 2 Ways, N.Y. Times, Oct. 10, 1990, at A12, col. 4. 
the third prong of the Miller test, which calls for an inquiry into the social value of the work and is meant to exclude from the ambit of constitutional protection the trivial or worthless, that is, literary or artistic material with no conceivable connection to the promotion of First Amendment values. Clearly, Mapplethorpe's work is not of that variety.

As a matter of aesthetics alone, the Mapplethorpe exhibit is a considerable achievement. His photographs are heartless; the flowers and bodies seem devoid of life-as I said, they appear almost sculptural - but they present an aesthetic vision that is original and in many respects stunning. The fact that a number of the most respected museums in the country ran the exhibition understandably made the work's aesthetic accomplishment the principal line of defense in the Cincinnati trial, and the testimony of leading figures from the national art establishment supported this aesthetic assessment. It is important, however, to understand that there is also a political dimension to Mapplethorpe's work and it too calls for protection under the Miller test, even more than does its aesthetic value. ${ }^{10}$ The political significance of the exhibition derives from its revelatory power: it brings into view the lives and practices of the gay community, a group long marginalized in American society that today is being ravaged by the AIDS epidemic. The show can be seen as a response to the angry protest of the gay community: "Silence = Death."

The Mapplethorpe photographs bear witness to the life of the gay community, boldly affirming its understanding of the erotic, portraying the full range of the community's sexual practices, some intimate, some quite brutal. The intimate encounters-the kiss, for example-might be grudgingly accepted by the casual museum-goer, while the scenes characterized as sadomasochistic in the " $\mathrm{x}, \mathrm{y}, \mathrm{z}$ series" force the same viewer to confront, and thus to critically reflect upon, the limits of his or her tolerance. Some of the shots in this series-for example, a picture of "a naked man with a bullwhip protruding from his posterior," as Senator Helms described it ${ }^{11}$ - shock conventional sensibilities in much the same way as burning a flag does. Like the confrontational tactics of gay political groups such as "ACT UP" and "Queer Nation," these photographs call on the viewer to recognize the gay community and its needs, a call made all the more urgent by the AIDS crisis which, many charge, has been allowed to continue unabated because it afflicts a group whose suffering has often been dismissed by an unsympathetic public as insignificant or, worse, as deserved. One of the most striking photographs in the exhibition, perhaps emblematic of the entire show, is a 1988 self-portrait of Mapplethorpe, taken

10. For an understanding of the political dimensions of Mapplethorpe's work, see Sischy, White and Black, NEW YORKER, Nov. 13, 1989, at 124 (review of shows by Minor White and Robert Mapplethorpe); A. Adler, The Tragedy of Contemporary Art in America (May 1990) (paper on file with author).

11. Senate Passes Compromise on Arts Endowment, N.Y. Times, Oct. 25, 1990, at C19, col. 1. The naked man to which Senator Helms refers is actually Robert Mapplethorpe. The photograph is entitled "SelfPortrait, 1978." 
in the year before his death, in which only his face and his right hand are luminous, as though set in a sea of blackness. His face appears worn, his eyes distant and still, his right hand is clenched, grasping a staff crowned with a skull, which, like Mapplethorpe himself, stares out at the viewer.

Seen in this way, the Mapplethorpe exhibition is, to use the Miller test, endowed with serious political value and on this basis alone, I venture to say, ultimately would have been protected from a criminal obscenity prosecution. But the other type of state response occasioned by the show-a loss of federal subsidies-appears more difficult to cabin. For most of our history, art in America has depended financially on the market and private charity, but for about the last twenty-five years the federal government, through the National Endowment for the Arts, has played an increasingly important role in financially supporting or subsidizing artistic activity. The appropriation for the NEA for fiscal year 1990 was approximately $\$ 144$ million. ${ }^{12}$ The Institute of Contemporary Art of the University of Pennsylvania had received some $\$ 30,000$ in NEA funds to assemble the Mapplethorpe retrospective. The question posed, in circumstances where the exhibition is protected from an obscenity prosecution, is whether it would have been constitutionally permissible for the government to deny that grant.

The controversy over funding the Mapplethorpe show began in June 1989 when Senator Helms learned that the show was about to open in the Corcoran Gallery of Art, a highly respected private museum in Washington, D.C. Senator Helms denounced Mapplethorpe's work as "filth" and "trash" and publicly objected to the use of federal funds to underwrite it. ${ }^{13}$ The curator of the Corcoran Gallery, presumably acting out of fear for the impact of the controversy on the NEA or on future applications to the NEA by the Corcoran, responded by canceling the plans for the exhibition.

The Corcoran's decision to cancel the show angered the artistic community, and, not surprisingly, did not satisfy or quiet the congressional critics. In the appropriations statute enacted that fall, Congress excluded from the NEA appropriations an amount equal to what the Institute of Contemporary Art had received for assembling the Mapplethorpe exhibition. That statute also required that the NEA give thirty days notice if it again intended to make a grant to the Institute. ${ }^{14}$ The concern was not, however, only with the Mapplethorpe exhibition. Helms and his followers hoped to generalize these sanctions so that in the future the funds appropriated by Congress could not be used to support work like Mapplethorpe's.

12. Act of Oct. 23, 1989, Pub. L. No. 101-121, tit. II, 103 Stat. 701, 738.

13. 135 CONG. REC. S8807-08 (daily ed. July 26, 1989) (statement of Sen. Helms).

14. Act of Oct. 23, 1989, Pub. L. No. 101-121, tit. I, 103 Stat. 701, 738. Particularized sanctions like these were also applied by the 1989 statute to the Southeastern Center for Contemporary Art in South Carolina, which had supported another work-a photograph of a crucifix in urine by Andres Serrano-that angered members of Congress. 
Defining the category of artistic work that would be ineligible for NEA funds proved to be an arduous task, taxing the imagination of the lawyers and the negotiating skills of the politicians, and the result was the so-called Helms amendment. It provided:

None of the funds . . . may be used to promote, disseminate, or produce materials which in the judgment of the National Endowment for the Arts ... may be considered obscene, including but not limited to, depictions of sadomasochism, homoeroticism, the sexual exploitation of children, or individuals engaged in sex acts and which, when taken as a whole, do not have serious literary, artistic, political, or scientific value. ${ }^{15}$

Although the Helms amendment borrowed the language of the Miller test, the statute swept more broadly, prohibiting funding for projects that do not fall within Miller's narrow definition of obscenity. Indeed, Senator Helms aspired to a rule prohibiting the government from funding all "indecent" art. ${ }^{16}$

The Helms amendment applied to funds appropriated by Congress in the summer of 1989, and, of necessity, expired when the period (fiscal year 1990) covered by it had come to an end. However, the controversy stemming from the funding of the Mapplethorpe show persisted and took on additional significance in the summer of 1990, when Congress took up the question of reauthorizing the NEA and making appropriations for it. The result, a statute passed in November 1990, just after the jury verdict in Cincinnati and shortly before congressional elections, did not reenact the original Helms amendment, but made changes in the statutory framework of the NEA that present an equally serious, but perhaps less visible, threat to artistic freedom.

On one level, the new statute appears to soften the censorial force of the Helms amendment. The statute still decrees that "obscenity ... shall not be funded,"17 but the determination of obscenity is left to the courts, and the standard articulated in the statute adopts the three-pronged Miller test. However, the new statute compounds the sanctions for an obscenity conviction by providing that if NEA funds are used to produce a work later decided by a court to be obscene, the funds will have to be repaid and the artist or recipient will be

\section{Id. § 304(a), 103 Stat. at 741.}

16. Senator Helms originally proposed the following amendment:

None of the funds authorized to be appropriated pursuant to this Act may be used to promote, disseminate or produce-

(1) obscene or indecent materials, including but not limited to, depictions of sadomasochism, homo-eroticism, the exploitation of children, or individuals engaged in sex acts; or

(2) material which denigrates the objects or beliefs of the adherents of a particular religion or non-religion; or

(3) material which denigrates, debases, or reviles a person, group, or class of citizens on the basis of race, creed, sex, handicap, age, or national origin.

H.R. 2788, 101st Cong., 1st Sess., 135 CONG. REC. S8806 (daily ed. July 26, 1989).

17. Arts, Humanities, and Museum Amendments of 1990, Pub. L. No. 101-512, § 103(b), 104 Stat. 1915, 1963 (1990). 
ineligible for further funding until full repayment is made. ${ }^{18}$ This provision is a matter of some concern, since an increase in sanctions increases the deterrent effect of state obscenity laws, thereby enhancing the risk that someone might be discouraged from engaging in conduct that is constitutionally protected.

Even more worrisome are the provisions in the 1990 statute consolidating the power of the NEA chairperson over grantmaking. In the past, applications for grants were reviewed by panels of experts, usually peers of the applicant consisting of museum professionals or artists involved in the same discipline. These panels were deemed "advisory," but in practice they dominated the process-approval by a panel usually insured receipt of a grant. ${ }^{19}$ The new statute anticipates a change in that procedure, vesting final authority for selection in the chairperson. ${ }^{20}$ Although the precise method by which that change will be effectuated is not specified, a commission appointed by President Bush in the midst of the controversy engendered by the Helms amendment points the way. Its report, issued in September 1990, should be read as part of the legislative history. ${ }^{21}$ The commission assumes that the chairperson will continue to use peer-review panels, but in order to concentrate responsibility for the selection in his or her hands, it recommends that the peer-review panels be asked to provide the chairperson with many more recommended applicants than can be funded. The chairperson will then pick and choose.

What standards will be used in making this choice? On this issue the 1990 statute is explicit. It directs the chairperson to ensure that "artistic excellence and artistic merit are the criteria by which applications are judged, taking into consideration general standards of decency and respect for the diverse beliefs and values of the American public ...."22 In directing the chairperson to attend to "general standards of decency," the 1990 statute, in effect, transforms the Helms amendment into an internal operating principle of the NEA. The chairperson is freed from the Miller standards and is able to deny funding to a project like Mapplethorpe's even though it is not within the constitutional definition of obscenity and thus not amenable to criminal prosecution. The chairperson could conclude that the project offends "general standards of

18. Id. $\S 103(\mathrm{~h}), 104$ Stat. at 1965-66.

19. See INDEPENDENT COMMISSION, REPORT TO CONGRESS ON THE NATIONAL ENDOWMENT FOR THE ARTS 26 (Sept. 1990).

20. Arts, Humanities, and Museum Amendments of 1990, Pub. L. No. 101-512, §106(c)(4), 104 Stat, 1915,1968 . The 1990 statute continues the prior procedure for reviewing grants, in which peer-review panels in each artistic discipline recommend applications for funding to the National Council on the Arts (a presidentially-appointed advisory body within the NEA), and the Council in turn recommends applications for funding to the chairperson. The 1990 statute gives the chairperson unambiguous power to veto these recommendations, but he or she may not elect to fund an application rejected by the Council.

21. See INDEPENDENT COMMISSION, supra note 19. The Independent Commission was established by Congress, and its members were appointed by President Bush. Act of Oct. 23, 1989, Pub. L. No. 101-121, $\S 304$ (c), 103 Stat. 701, 742.

22. Arts, Humanities, and Museum Amendments of 1990, Pub. L. No. 101-512, $\S 103$ (b), 104 Stat. $1915,1963$. 
decency," even though it has, within the meaning of the Supreme Court's standards, serious aesthetic or political value.

In the middle of December 1990, Chairperson John E. Frohnmayer sought to reassure an NEA advisory body (the National Council on the Arts) on this issue, since it had just adopted a resolution opposing the promulgation of explicit decency standards. He said, "I am not going to be a decency czar here."23 Weeks later he approved grants to two controversial performance artists-Karen Finley and Holly Hughes-whose applications had previously been deferred. ${ }^{24}$ But in light of the overall structure of the statute, as well as the position of the present administration on these issues and Frohnmayer's previous performance-especially the extraordinary measures he used to implement the Helms amendment, even against the advice of the same advisory body ${ }^{25}$-his disclaimer rings hollow and his approval of the Finley and

23. Arts Council Rejects Decency Rules for Advisers, N.Y. Times, Dec. 15, 1990, at 19, col. 1.

24. Arts Endowment Reverses a Stand, N.Y. Times, Jan. 5, 1991, at 9, col. 3. Finley, Hughes, and two other artists sued the NEA after their previous applications for grants were denied by Frohnmayer in the summer of 1990 for, they allege, political rather than artistic reasons. The grants to Finley and Hughes in January 1991 were two among 1200 grants announced that month; we do not know, of course, which ones were not approved. Or, as Hughes said when she learned her grant was approved, "This might get tossed my way, but I think other artists, whose identities are controversial-their race, their gender, their sexual orientation-are just going to be weeded out by the new internal changes in the NEA ...." Id.

25. Initially, Frohnmayer opposed the Helms amendment. See Nomination Hearing Before the Senate Comm. on Labor and Human Resources on John E. Frohnmayer to be Chairperson for the National Endowment for the Arts, 101st Cong., 1st Sess. 23 (1989). But after it was enacted he instituted a requirement that artists and organizations accepting federal funds sign a pledge to comply with the Helms amendment. See Grants Rule Testimony By Arts Chief, N.Y. Times, May 2, 1990, at C13, col. 1. These pledges caused a furor even greater than the Helms amendment itself, and the National Council on the Arts recommended that the requirement of signing a pledge be dropped. Frohnmayer refused to do so. Moreover, where the NEA had made contributions to the general operating budgets of organizations, like collectives or galleries, that were suspected of having run afoul of the Helms amendment, the NEA demanded the names of every artist the organization supported and a description of every work it planned to exhibit. These measures were foreshadowed by an action Frohnmayer took in November 1989, less than a month after he assumed office, when he rescinded funding for an exhibition on AIDS entitled "Witnesses: Against Our Vanishing" on the grounds that it was too "political." In justifying this action he pointed to an artist's essay in the catalogue severely criticizing, among others, New York City Cardinal John O'Connor and Senator Helms for their positions on homosexuality and AIDS issues. As Frohnmayer then put it, "I strongly believe in the ability of people to speak their minds under the First Amendment, but the endowment should not be funding that discourse." Front Page: NEA Chairman Does Turnabout on AIDS Exhibition, ART IN AMERICA, Jan. 1990, at 31. Frohnmayer reversed his decision within two weeks, but restricted grant funds from being used for the catalogue. Arts Endowment Withdraws Grant for AIDS Show, N.Y. Times, Nov. 9, 1989, at A1, col. 1; National Arts Chief, in a Reversal, Gives Grant to AlDS Show, N.Y. Times, Nov. 17, 1989, at A1, col. 1; Frohnmayer's Folly, NEW ART EXAMINER, Feb. 1990, at 20. For an analysis of the administration of the NEA under the Helms amendment, and a sense of what the 1990 statute is likely to bring, see generally Wallis, Bush's Compromise: A Newer Form of Censorship?, ART IN AMERICA, Nov. 1990 , at 57.

The pledge requirement resulted in a number of lawsuits which were brought by organizations whose fiscal year 1990 grants were withheld because they refused to sign the pledge. One such suit was resolved in January 1991 when the federal district court in Los Angeles held the pledge requirement unconstitutionally vague. Bella Lewitsky Dance Found. v. Frohnmayer, 1991 U.S. Dist. Lexis 332, No. 90-3616 (C.D. Cal. Jan. 9, 1991). A second suit, brought by the New School for Social Research in New York, was settled the next month, when the NEA agreed to abandon the pledge requirement for all fiscal year 1990 recipients. Arts Agency Voids Pledge On Obscenity, N.Y. Times, Feb. 21, 1991, at C14, col. 6. However, a provision in the 1990 statute might be read as giving rise to an analogous requirement insofar as it requires applicants for NEA funds to provide "an assurance that the project . . . will meet the standards of artistic excellence 
Hughes applications should not be taken as a bold reversal of policy. The risk remains great that, in the end, Helms will have his way, and grants will be denied by the Endowment for projects like Mapplethorpe's on grounds of indecency, even though they cannot constitutionally be prosecuted criminally for obscenity.

Most commentators and perhaps a majority of the justices would not see this double standard as posing a First Amendment problem of any sort, but my inclination is just the opposite. My analysis proceeds on the assumption that government subsidies are not gifts or bonuses for acts that would have occurred without them. Subsidies are not, I assume, redundant, but rather generally have a productive value: they bring into existence art, performances, or exhibitions that would not have existed but for the subsidies. They do this either by providing artists with an income, by defraying costs associated with a show, or by creating incentives for artists or the distributors of art. The NEA grant to the Institute for Contemporary Art for the Mapplethorpe exhibition encouraged or made possible the Mapplethorpe exhibition, and the denial of a subsidy would have had the effect of withdrawing that exhibition from public view or limiting its availability. A denial of a grant does not have the brutal consequences for the individual that might, on the worst of days, attend a criminal prosecution for obscenity, when the artist languishes in prison. From the perspective of the public, however, its effect is similar: It keeps art from us.

Of course, even without the government grant the artistic endeavor may survive and be made available to the public. Alternative sources of funds might be found, as might have occurred in the case of the Mapplethorpe show itself if the original grant had been denied the Institute of Contemporary Art. In that sense, the ban effectuated by a denial of grants, even federal ones, is not absolute and universalistic. To borrow a term from Harry Kalven, it is a "partial sanction." ${ }^{26}$ I believe the same might well be said of the criminal prosecution.

and artistic merit required by this Act." Arts, Humanities, and Museum Amendments of 1990, Pub. L. No. $101-512, \S 103(\mathrm{~g}), 104$ Stat. 1915, 1964-65 (1990). The statute goes on to require that grant payments in most cases be made in installments, with the final one-third withheld until "the Chairperson finds that the recipient of such assistance is complying substantially ... with the conditions under which such assistance is provided to such recipient." $I d$.

26. H. KaLVEN, A WORTHY TRADTION: FREEDOM OF SPEECH IN AMERICA 301-03 (1988). Kalven distinguishes the criminal sanction (referred to as the direct or total sanction) from partial sanctions on the grounds of motivation:

The criminal sanction is not ambiguous as to the objective of the state. Its purpose is to prevent the publishing of the disfavored message; it has no other purpose than to dissuade the speaker from saying that. In contrast, there is another set of situations in which only a privilege of some sort is at stake, and the state objective-and motivation-may be highly ambiguous.

Id. at 301. But this distinction appears to rest on a mischaracterization, or perhaps an incomplete description, of the purposes of the state. In the criminal context, the state prosecution might threaten to suppress the speech, as Kalven asserts, but its purpose or motivation is much more complex and indeed is not dissimilar or less ambiguous than in the subsidy context. For example, it could be said that the purpose or motive of an obscenity prosecution is not to suppress the speech; rather, the purpose might be to preserve or protect norms regarding sexuality or morality, or to prevent rape or other sexual violence, which in turn might require suppression of speech. 
An artist or museum director might decide to suffer the sanction of the criminal law (for example, pay the fine or spend some time in jail) rather than remain silent. Or, as became evident in the case of Mapplethorpe, the criminal sanction might be limited in its geographic reach. The Mapplethorpe exhibition provoked an obscenity prosecution in Cincinnati, but not in Philadelphia or Hartford (where it was shown previously) or in Boston (where it moved subsequently). In the American federal system, the administration of the criminal law is largely the responsibility of states and localities, all of which have jurisdictions of limited scope.

It is thus appropriate to assume that the effect of a denial of a grant is roughly equivalent to that of a criminal prosecution, in that each tends to silence the artist or, in the case of exhibitions, make the artist's work unavailable to the general, museum-going public. But a complication is introduced when it comes time to define the constitutional wrong. In the criminal context, the wrong can be defined in purely quantitative terms, that is, in terms of the overall quantity or amount of speech available to the public. Indeed, our reaction to the obscenity prosecution is largely shaped by the common assumption that the more speech the better, the function of the three-pronged definition of obscenity is to keep that silencing effect to an absolute minimum. In the case of subsidies, however, an additional element is needed to define the wrong, because the presence of scarcity transforms the decisional process into an allocative one.

The amount of money to be dispensed by government will always be exceeded by the number of applicants, and thus of necessity a competition will arise among the applicants for the grants. A grant given to one is necessarily denied to another. Giving a grant for the Mapplethorpe exhibition enhances the availability of his work to the public, but that money is simultaneously being denied to another artist, thereby silencing him or her or limiting the availability of that artist's work. Conversely, while denying a grant for the Mapplethorpe show might have impaired the availability of his work to the public, one must also assume that the funds withheld would not have lain idle but would have been allocated to some other artist, allowing that artist's work to flourish. This means that the silencing produced by the denial of the subsidy is of a different nature than that produced by a criminal prosecution. The difference arises from the fact that silencing is a necessary concomitant of every allocative decision. ${ }^{27}$ Does one artist's expression have greater claim to scarce state subsidies

27. Recent feminist attacks on pornography maintain that the free circulation of publications that treat women as sex objects tends to silence women; thus, failing to prosecute pornography might also produce a silencing effect. See generally C. MACKINNON, FEMINISM UNMODIFIED 127-213 (1988). From this perspective it appears that speech itself, rather than the act of the state, is the censor, but under a theory that makes state inaction a form of action, responsibility can be traced to the state through the decision not to prosecute. While I find myself sympathetic to much in this line of argument, it does not dissolve the distinction between the subsidy and criminal contexts. The same silencing effect that is decried by feminists may be present when a grant is awarded, so a grant to some artists could be said to have two silencing ef- 


\section{than another's?}

At this point, the temptation is great to retreat from the concern with effect and, in contrast to the criminal context, to define the constitutional wrong in purely procedural terms. While the wrong in the criminal context consists of the silencing effect, which the constitutional definition of obscenity tries to keep to a minimum, the wrong in the allocative context is not the silencing effect but rather the reason or criterion upon which the allocation in question was based. Under this view, the First Amendment would be reduced to a rule requiring that the choice among applicants not be made on the basis of a forbidden criterion.

To support this view, an analogy might be drawn to that body of constitutional doctrine concerning the treatment of women and racial minorities under conditions of scarcity, say, in employment. In that context, the Court has abandoned the approach it had taken in the late 1960's and early 1970's, and beginning with Washington $v$. Davis in 1976, has taken the position that the constitutional wrong consists not of the effect (denial of employment) but the use of a forbidden criterion (race or sex). ${ }^{28}$ I have great difficulty with this shift in the Court's approach to equal protection or discrimination issues, and even more so with the notion of transferring it to free speech.

While in the discrimination context it might be possible to construct a finite and rather well-understood list of forbidden criteria (race, religion, national origin, sex, etc.), in the free speech context no such list readily suggests itself. What are the criteria prohibited by the First Amendment? In a library case, Justice Brennan grappled with a similar problem and, in an effort to honor the general norm of content-neutrality, used two notions to define the forbidden criterion: disagreement with an idea and a desire to suppress that idea. He said that a library's decision to remove a book from its collection cannot be based on a disagreement with the ideas presented in that book and a desire to limit access to those ideas. ${ }^{29} \mathrm{But}$, as is the case with any allocative decision, the

fects-one linked to the denial of a grant to someone else, and another that flows from the free circulation of the subsidized material.

28. Compare, e.g., Gaston County v. United States, 395 U.S. 285 (1969); Griggs v. Duke Power Co., 401 U.S. 424 (1971); Swann v. Charlotte-Mecklenburg Bd. of Educ., 402 U.S. 1 (1971) and Keyes v. School Dist. No. 1, 413 U.S. 189 (1973) with Washington v. Davis, 426 U.S. 229 (1976); Village of Arlington Heights v. Metropolitan Hous. Dev. Corp., 429 U.S. 252 (1977); Personnel Adm'r v. Feeney, 442 U.S. 256 (1979) and Wards Cove Packing Co. v. Atonio, 490 U.S. 642 (1989). Sometimes the Court casts this procedural approach in terms of "motive" or "intent" rather than "criterion" or "basis." For an analysis of this shift in the school context, see my statement to the Second Circuit's Annual Judicial Conference, 74 F.R.D. 219, 276 (1976); Fiss, School Desegregation: The Uncertain Path of the Law, 4 PHIL. \& PUB. AFF. 3 (1974).

29. Board of Educ. v. Pico, 457 U.S. 853 (1982). In this case, Justice Brennan, speaking only for a plurality of the Justices, wrote: "If petitioners intended by their removal decision to deny respondents access to ideas with which petitioners disagreed, and if this intent was the decisive factor in petitioners' decision, then petitioners have exercised their discretion in violation of the Constitution." Id. at 871 (footnote omitted). He went on to identify a permissible criterion: "On the other hand, respondents implicitly concede that an unconstitutional motivation would not be demonstrated if it were shown that petitioners had decided to remove the books at issue because those books were pervasively vulgar." Id. As a general matter, Justice 
acquisition and removal decisions of a library must reflect some judgment as to what ideas to make available to the readers, and what not to make available. It is not at all clear why the First Amendment would prohibit that judgment from being based on agreement or disagreement with those ideas, or any other reaction to the content of the material. In the allocative context, content neutrality makes little sense, for a choice must be made among competing ideas, and for that purpose the official entrusted with that decision must look to content. Surely, books should be purchased, or artistic awards granted, on the basis of content.

Moreover, even if the forbidden criteria could be identified with some specificity, a First Amendment approach that looks to the underlying criterion in judging the validity of allocative decisions would be extremely difficult to administer, the more so under the 1990 NEA statute. Such an approach entails an inquiry into the grounds or basis of a decision, and, as we know from the discrimination context, often the real reason for an allocative decision cannot be authoritatively ascertained. Imagine that a peer-review panel provides Frohnmayer with a list of a dozen applicants under circumstances where only one can be funded. The Chairperson chooses the one, and then justifies his decision on grounds of "artistic excellence." How can a court be certain that this is the real reason for his decision and that he is not basing it on some (still to be defined) forbidden criterion or, to use a phrase of Brennan's from the library case, that he is not impelled by an "unconstitutional motivation"? Granted, the legal system might create presumptions or devise various rules regarding the burden of proof to cope with this problem, but all these devices will invariably reflect some understanding of effect or impact. Similarly, the legal system will have to fall back on notions of effect, as it has done in the discrimination context after Washington v. Davis, to cope with the problems of multi-member decisional agencies (one official bases his or her decision on the forbidden criterion while the others do not) or mixed motives (the allocative decision is only partially based on the forbidden criterion).

It is also hard to understand the theoretical basis of an approach looking to the criterion of decision. In the discrimination context, the criterion approach rests upon considerations of individual fairness-it is arbitrary to judge someone on the basis of a criterion (such as race or gender) that has no discernible connection to productivity and over which the individual has no control. I, for one, believe it is a mistake to reduce the constitutional ideal of equality to

\footnotetext{
Brennan's approach to the First Amendment, like the one advanced in this piece, can be understood as premised on the desire to protect the access of the public to controversial ideas and to avoid the pall of orthodoxy. The emphasis in Pico upon the criterion of decision is inconsistent with such an approach, as Justice Rehnquist pointed out in dissent, $i d$. at 915-18. Justice Rehnquist would allow the state a free hand in awarding grants, except when it was shown that the decision was "primarily 'aimed at the suppression of dangerous ideas. " FCC v. League of Women Voters, 468 U.S. 364, 407 (1984) (Rehnquist, J., dissenting) (quoting, inter alia, American Communications Ass'n v. Douds, 339 U.S. 382, 402 (1950)).
} 
considerations of individual unfairness, ${ }^{30}$ but however appropriate such a reduction might be in the discrimination context, it seems particularly inappropriate in the speech context. The First Amendment is a guarantee of collective self-determination, a method for making certain that the people know all that they must to exercise their sovereign prerogative, and for that reason, the focus should be on the condition of public discourse, not the process by which that condition was created. ${ }^{31}$ Keeping ideas and information from the public, not the unfair treatment of the speaker, is the gist of the constitutional wrong, and from that perspective a concern with the basis for an act that keeps ideas from the public makes little theoretical sense. As Justice Rehnquist put it in the library case, though only to score a debater's point, "If Justice Brennan truly recognizes a constitutional right to receive information, it is difficult to see why the reason for the denial makes any difference."32

In the discrimination context, some have defended the criterion approach on the ground that it maintains a measure of state neutrality: if a judgment is based on some meritocratic criterion, such as performance on standardized tests, the state can achieve a measure of neutrality on issues of race even though it must make a choice among applicants for a job. A similar thought might account for the use of the criterion approach in the religion context in order to maintain the separation of church and state, and might have some sway in the speech area too, where state neutrality is also assumed to be a good. We want the state to be neutral between competing viewpoints, or competing conceptions of the good life, and it might be assumed that neutrality could be achieved by having allocative decisions based on some meritocratic criterion such as "artistic excellence."

This assumption, however, is unfounded. The ideal of neutrality in the speech context not only requires that the state refrain from choosing among viewpoints, but also that it not structure public discourse in such a way as to favor one viewpoint over another. The state must act as a high-minded parliamentarian, making certain that all viewpoints are fully and fairly heard. In the allocative context, the state's decision will necessarily have an impact on which viewpoints are heard by the public, and the state's obligation of neutrality requires that it make certain that the public debate is as rich and varied as possible. The use of a meritocratic criterion cannot insure the discharge of this duty, for it disregards the impact of that decision on public debate; as we learned in the discrimination context, a seemingly neutral criterion does not insure a neutral impact. A meritocratic criterion, such as a standardized test, may still have a discriminatory effect, because it may especially disadvantage minorities. Similarly, in the speech context, the use of a meritocratic criterion, such as "artistic excellence," for determining who is heard may silence view-

30. See Fiss, Groups and the Equal Protection Clause, 5 PHL. \& PUB. AFF. 107 (1976).

31. See generally supra note 2; Fiss, Free Speech and Social Structure, 71 IowA L. REv. 1405 (1986).

32. Pico, 457 U.S. at 917 (Rehnquist, J., dissenting). 
points, or skew the debate, depending, of course, first, on the specific content given the (rather broad-ranging) notion of "artistic excellence" and, second, on the condition and needs of public discourse.

For these reasons, the judiciary should not adopt a criterion approach in judging allocations or other affirmative exercises of state power. Rather, it should keep the focus on effects, specifically the effect the exercise of state power has on public debate. In a case like Mapplethorpe's, the denial of a grant would impoverish public debate because it would reinforce the prevailing orthodoxy on an issue of great public importance, the status of the gay community, and the basis for that denial, whether it be aesthetics, taste, or ideology, is of no constitutional significance. The constitutional wrong of an obscenity prosecution arises from the effect such an exercise of state power has upon public discourse, and although there is an analytic difference in the subsidy situation, arising from the scarcity factor, the focus should remain on the effect of the government action. The difference between the two situations requires not an abandonment of the concern with effect, but a more refined conception of effect and the introduction of a more qualitative perspective in the allocative context: A court must determine what effect a challenged allocative decision would have upon public debate. To use the now talismanic phrase, a court must ascertain whether the allocative decision would contribute to a debate on national issues that is "uninhibited, robust, and wide-open,"33 or whether its effect would be just the opposite.

Such a judgment requires a sense of the public agenda, a grasp of the issues that are now before the public and what might plausibly be brought before it, and then an appraisal of the state of public discourse, not to decide who is right or who is wrong, but to see whether all the positions on the issue are being fully and fairly presented so that the people can make a meaningful choice. These kinds of judgments must be context specific and perhaps for that very reason seem extremely arduous. The allure of the criterion approach is that it renders these kinds of judgments unnecessary. They are, however, required by the grandest aspirations of the Constitution and are not beyond our reach. In fact, they are analogous to the judgments made by the great teachers of the universities of this nation every day of the week as they structure discussion in their classes, and, turning to the case at hand, are implicit in our assessment of the Mapplethorpe controversy: the special egregiousness of the denial of NEA funding in such a case arises from the fact that it would perpetuate and reinforce the orthodoxy that tends to marginalize the gay community. Even those on the side of censorship in this controversy would acknowledge this effect; in fact, they may wish it to occur.

The effects approach calls for judgments that have analogues throughout the law, not just in discrimination cases, but also in such widely disparate areas

33. New York Times Co. v. Sullivan, 376 U.S. 254, 270 (1964). 
as antitrust, when a judge determines the parameters of a relevant market, and torts, when a judge evaluates the frontiers of scientific possibility in order to adjudicate a state-of-the-art defense. Admittedly, we may have a special reluctance for allowing these judgments in the speech area for fear that the judicial power will become an instrument for constricting rather than broadening public understanding, or even worse, for favoring one viewpoint over another. In assessing the significance of this risk, however, two considerations must be kept in mind.

First, the courts will not make these judgments in a vacuum, but will be subject to intense scrutiny of the critical community that attends to matters judicial, in this instance, not just lawyers and the press, but also the leaders of the art world. The Mapplethorpe controversy has been remarkable in its capacity to mobilize the art community and to spur countless museums and theaters across the country into action. If judicial review of a funding decision were required, members of this community might participate in the judicial proceedings, as they did in the Cincinnati trial, to help the court appreciate the political and aesthetic significance of the work denied funding. Or, they might mobilize the public, as they did in response to the Helms amendment, to make certain that the judiciary does not shirk its duty or become an instrument of censorship while reviewing NEA practices under the effects standard. The courts may be less responsive to such criticism than institutions that are politically accountable, but they are not immune to it.

Second, a rejection of the effects approach, and a willingness to judge allocations on the basis of the decisional criteria, would invite the very same risk, namely, that courts will become an instrument for perpetuating an orthodoxy, but it would do so in an even more flagrant manner. The evidentiary difficulties of sorting out the real reason for a decision and impeaching the stated reason will tilt the process in favor of the NEA, and almost invariably lead to the endorsement of its decisions.

Even under the effects approach, state officials are likely to continue using meritocratic criteria, such as "artistic excellence," to allocate grants. The funding agency will select what it understands to be the best or most worthy recipient. The agency will, however, come to understand that its standards of excellence will have to be either interpreted or modified in light of the constitutional commitment to robust public debate. When a criterion such as "artistic excellence" is used in such a way as to have the consequence of keeping from public view art that presents ideas and positions otherwise absent from public discourse, and thus to constrain public debate, it will have to be qualified in order to fulfill the purposes of the First Amendment. ${ }^{34}$

34. The use of certain meritocratic criteria in a way that effectuates a delegation of power over funding decisions to the artistic community might-given certain background assumptions about the nature of that community-produce the desired effect: robust public debate. Under this scheme, effect remains the touchstone of the constitutional wrong, and a criterion approach is deployed for instrumental reasons, to 
Considerations of merit will also have a role to play when it comes time for the judiciary to review a denial of a grant. As in the early discrimination cases, where the Court looked to effects, ${ }^{35}$ judgments of artistic merit emerge as a justification or defense for a course of conduct that produces the undesirable effect (the perpetuation of an orthodoxy). As a defense, considerations of artistic merit fix the outer limits on the state's duty to avoid the production of that effect, and the precise location of that limitation depends on the gravity of the effect produced and the urgency of the justification for what the state has done. The duty to attend to effects does not mean in the speech area, any more than it did in race, an end to merit. What it does mean is either a reexamination of the notions of merit that underlie funding decisions or, alas, a sacrifice of some of the values that might be furthered by notions of merit that do not incorporate, or, in fact, are antagonistic to, the constitutional goal of producing a public debate that is worthy of our democratic aspirations.

In determining whether there would in fact be such a sacrifice, and what its magnitude might be, it is important to understand how art typically performs its educative function: not by advancing a single viewpoint, in the way that a commercial advertisement or political propaganda might, but by leading the viewer to contemplate a familiar subject from a new perspective or by bringing the unfamiliar into focus. The best art leads us to ponder, reconsider, suspend conventional wisdom, and reject unreflective assumptions and expectations. Subjectively, art provokes an attitude of inquisitiveness; objectively, it reveals aspects of an experience or subject matter-in the case of Mapplethorpe, sexuality - that we have previously misperceived or ignored. The best art is art that enriches public discourse, not in the manner Stalin made familiar, but by opening our eyes and thereby transforming our understanding of the world.

The Mapplethorpe exhibition was not by any means a simple and straightforward celebration of homosexuality or gay life, nor is that the basis for its special claim for public support. The Mapplethorpe exhibition brought the gay community into focus, but only to complicate our understanding of it. Certainly, the photographs are defiant affirmations of gay sexuality, but they are also something more. Their manner of presenting their subject though classically simple composition and immaculately clear, precise renderings of sensuous surfaces, recalling fashion photography, has the effect of making the activities depicted appear staged or theatrical, as if the participants were merely performing for others, or as if their self-awareness depended on how they appear in others' eyes. These images suggest a parallel between, on the one hand, a theatrical sexuality that may have as much to do with posing, and even pain,

be abandoned whenever it fails to produce the desired effects. $r$

35. See Griggs v. Duke Power Co., 401 U.S. 424 (1971); Fiss, A Theory of Fair Employment Laws, 38 U. CHI. L.R. 235 (1971); Fiss, Gaston County v. United States: Fruition of the Freezing Principle, 1969 SUP. CT. REV. 379; Note, Reading the Mind of the School Board: Segregative Intent and the De FactolDe Jure Distinction, 86 YALE L.J. 317 (1976). 
as with emotion, ${ }^{36}$ and, on the other hand, the social position of gay people in contemporary America, simultaneously marginalized and subjected to intense and derisive public scrutiny. Walking through the exhibit, one is led to wonder whether social marginalization has been internalized in homosexual practice-whether homosexual self-understanding has been marred and distorted by public loathing and opprobrium. These photographs do not constitute a propagandistic endorsement of homosexuality, or anything else, but invite us-all of us - to reconsider our understanding of, and attitude toward, homosexual orientation and practice. In the case of the Mapplethorpe photographs, there is no sacrifice of artistic or democratic values. They are, at once, great art and a great lecture, an inspired contribution to a public debate that aspires to be "uninhibited, robust, and wide-open."

There is, of course, a danger the government might respond to judicial review of decisions denying grants to such controversial and provocative works by withdrawing from the field altogether. The state might abandon the subsidy program, or at least seriously cut back on it, in which case speech would be a loser to an even greater extent than when the government denies a grant to some controversial artist. The Mapplethorpe controversy did indeed result in diminution of the NEA appropriation in the 1989 funding statute, and it provoked some to call for an end to government funding for the arts. ${ }^{37}$ In the criminal context, there is no comparable risk because a state retreat-no prosecution or repeal of the obscenity statute-is assumed under standard doctrine to promote speech values.

It seems to me, however, that this difference between the criminal and allocative contexts requires a measure of caution, not a difference in standards or general approach. The reduction of the overall level of spending is a contingency, not a necessity. The judiciary should not assume that it will materialize, and in fact it should do all that it can to prevent that from happening, always keeping open the possibility that, in the worst of all possible worlds, it might have to freeze the level of spending or even mandate an increase in levels of spending to protect First Amendment values. The First Amendment commands that Congress make no law abridging the freedom of speech, but as in the case of the heckler's veto, where a speaker is left to the mercy of an angry mob, a decision of the state not to act-to go out of the funding business altogether-might itself be a form of action prohibited by the First Amendment. ${ }^{38}$ The

36. As one of the experts called by the defense in the Cincinnati trial put it, when questioned about some of the sadomasochistic photographs in the " $x, y, z$ series," "It's the tension between the physical beauty of the photograph and the brutal nature of what's going on in it that gives it the particular quality that this work of art has." Grundberg, Critics Notebook: Cincinnati Trial's Unanswered Question, N.Y. Times, Oct. 18, 1990, at C17, col. 3 (quoting Jacquelynn Bass, Director, University Art Museum in Berkeley, California).

37. See 135 CONG. REC. H3637 (daily ed. July 12, 1989) (statement of Rep. Rohrabacher); Safire, Stop Subsidizing the Arts, N.Y. Times, May 18, 1990, at A31, col. 6.

38. H. KALVEN, supra note 26, at 89-91, 97-100; see also supra note 27 (discussion of failure of government to act in context of pornography). 
broad discretion allowed the legislature in making budgetary decisions cannot be used in a way that interferes with the attainment of constitutional goals, or, more concretely, with the judiciary's efforts to further these goals by reviewing the programs established by the legislature and the way they have been administered by the executive.

In the school desegregation area, strong judicial intervention created a risk that the school boards would close their schools rather than integrate. It is remarkable, however, that over a thirty year period, involving thousands and thousands of court desegregation orders, that risk materialized only on two or three occasions, and in each instance, the judiciary somehow found that it had the power to order that the schools be reopened. ${ }^{39}$ This power was not defeated by sloganistic assertions that "there is no constitutional right to a public education" (which have recurred in the art context in slightly different form); this power of the judiciary has recently been affirmed by the Supreme Court in the Kansas City school case, in which a federal court ordered the state to raise taxes to finance the court's desegregation plan. ${ }^{41}$

As a purely ideological matter, the argument in favor of a double standard, sharply differentiating between subsidies and criminal prosecutions, and applying a distinctly more relaxed standard to the former, has many roots, but perhaps none is more important today than the capitalist ethos that transforms money into power and gives to each productive agent prerogatives over the property or money he or she has earned. Capitalism contemplates private ownership of the means of production and, even more crucially, a sharply differentiated incentive structure. The best get paid the most. For this incentive structure to work as promised, the rewards distributed for efficient production must be secured from the rapacious greed of the less well paid and, even more, must empower those who are fortunate enough to receive these rewards. The private property system presupposed by capitalism is intended to provide to each individual, with respect to the money he or she has earned, a sense of entitlement as well as a sense of security. You may use your money in the way you wish, spend it on the goods you want, give it to anyone you wish, or deny it to those you do not like, approve of, or admire.

There is no reason in the world why the sense of entitlement associated with private property should extend to the money in the public treasury, which is not earned but rather collected and held for public purposes. But in this triumphant moment of capitalism, the norms of that economic system cannot easily be confined. Money is money, and what is worse, we tend to think of the state

39. Griffin v. County School Bd., 377 U.S. 218 (1964); Lee v. Macon County Bd. of Educ., 231 F. Supp. 743 (M.D. Ala. 1964); see also United States v. Plaquemines Parish School Bd., 291 F. Supp. 841 (E.D. La. 1967) (school board may not reduce funding for newly integrated schools to encourage white flight to private, segregated schools).

40. See, e.g.. INDEPENDENT COMMISSION, supra note 19, at 85 (Legal Task Force's consensus statement that "there is no constitutional obligation on the part of the federal government to fund the arts").

41. Missouri v. Jenkins, 110 S. Ct. 1651 (1990). 
in much the same way as we would an individual entrepreneur, confusing Uncle Sam and Donald Trump. We personify the state and accord it the privileges of a productive agent, thinking that the decision of the government to support activities should be wholly discretionary and that government should not be obliged to support activities it does not like, approve of, or admire. ${ }^{42}$

What is needed here by way of remedy is a sense of limits. One can readily appreciate the marvels of capitalism as an economic system, as a way of providing for the efficient delivery of goods and services, without believing that each and every decision of social life-say of the political domain or of the family-should be dominated by the norms of that economic system. It would be sad if the First Amendment became captured by the economic system and if we thus allowed free speech to be compromised by our desire to protect private property. The revenues collected by the state constitute a public resource, to be used for public purposes, and I can think of no higher purpose for these funds than the preservation of democracy, bringing before the public viewpoints and options that otherwise might be slighted or ignored. Government subsidies, whether they be for the arts or education, should not be used to reinforce the prevailing orthodoxy, but rather to further the sovereignty of the people by provoking and stirring public debate, so that we may live as we do because we want to, not because the familiar is all we know or can imagine.

42. As a corollary, it is sometimes argued that a grant or government subsidy constitutes an endorsement or approval of the subsidized work or its message - as though government or individual taxpayers are speaking. Senator Helms took this argument to a new extreme when he reacted to the jury verdict in Cincinnati. "A Helms aide explained," according to the New York Times, "that the Senator believed the NEA grant . . . had, in effect, transformed the photographs into Government-approved art, making it impossible for a jury to declare them obscene." Cincinnati Jury Acquits Museum in Mapplethorpe Obscenity Case, N.Y. Times, Oct. 6, 1990, at 1, col. 1. To reassure Senator Helms on this point, the 1990 statute specifies that "[t]he disapproval or approval of an application by the Chairperson shall not be construed to mean, and shall not be considered as evidence that [the art funded by the grant] is or is not obscene." Arts, Humanities, and Museum Amendments of 1990, Pub. L. No. 101-512, § 103(b), 104 Stat. 1915, 1963-64 (1990). In my view, the danger of attribution or endorsement that Helms fears is small, especially when the subsidization is done under force of law (a court order or the Constitution). No one will assume that the Mapplethorpe show expresses the viewpoint of the government on some particular issue (sadomasochism or homosexuality), or even less, of individual taxpayers who might be offended by the work. In any event, a simple disclaimer can avoid that danger. On the other hand, a decision by the NEA to fund a project ideally would represent some judgment from the agency, subject to judicial review, about the issues that should be considered by the public and the range of views that should be heard, or that are missing from the public debate. These judgments are analogous to the ones made by the state in public education and public broadcasting and far from being denied to the state by the First Amendment, seek to vindicate its highest purposes. 